\title{
Morbid Obesity in Diabetes Mellitus Type 2 and Exenatide
}

\author{
María Angeles Ibañez Gil ${ }^{1}$, Alfonso López Ruiz ${ }^{2}$, Alicia Hernández Torres ${ }^{3}$, \\ Ana Belén Hernández Cascales ${ }^{4}$, Pedro Pujante Alarcon ${ }^{4}$, María Dolores Hellín Gil ${ }^{4}$ \\ ${ }^{1}$ Health Center Mariano Yago, Yecla, Spain; ${ }^{2}$ Pharmaceutical Care Research at the University of Granada, Granada, Spain; \\ ${ }^{3}$ Infectious Internal Medicine of the Hospital University Virgen de la Arrixaca, Murcia, Spain; ${ }^{4}$ Endocrinology and Nutrition Service \\ of the Hospital University Virgen de la Arrixaca, Murcia, Spain. \\ Email: lablilly@gmail.com
}

Received November $8^{\text {th }}, 2013$; revised December $31^{\text {st }}, 2013$; accepted January $15^{\text {th }}, 2014$

Copyright (C 2014 María Angeles Ibañez Gil et al. This is an open access article distributed under the Creative Commons Attribution License, which permits unrestricted use, distribution, and reproduction in any medium, provided the original work is properly cited. In accordance of the Creative Commons Attribution License all Copyrights (C) 2014 are reserved for SCIRP and the owner of the intellectual property María Angeles Ibañez Gil et al. All Copyright @ 2014 are guarded by law and by SCIRP as a guardian.

\begin{abstract}
Worldwide, the prevalence of diabetes and obesity is increasing in recent years in developed countries. The first step of treatment is changes in lifestyle and in case of failure to initiate drug treatment. In our case, the patient with morbid obesity and glucose intolerance to metformin therapy was initiated without achieving weight loss and loss of glycemic control after 6 months of treatment. It was decided to add exenatide as an alternative to bariatric surgery. At the end of the study (12 months), it showed a weight reduction of $20.8 \%$ (Table 1 ), $20.83 \%$ BMI, glycosylated hemoglobin decrease of 2 points, and improved the lipid profile. So exenatide may be an acceptable option in the use of patient profile. It would be necessary to seek a new alternative treatment with minimal side effects and less healthcare costs.
\end{abstract}

\section{KEYWORDS}

Type 2 Diabetes and Obesity; Exenatide

\section{Introduction}

The prevalence of diabetes in the world is parallel to the increase in obesity. It is estimated that there are now 300 million and 175 million obese patients with type 2 (DM2), a figure that will reach 366 million by 2030, with a peak in the developing countries. Therefore, the DM2 comorbidity is, genuinely, most associated with excess weight, so that $90 \%$ of patients with type 2 diabetes are overweight and in this context, morbid obesity (BMI $\geq$ $40 \mathrm{~kg} / \mathrm{m}^{2}$ ) is multiplied by more than 10 of the risk of developing DM2. In patients with morbid obesity who have not yet DM2, excess fat is associated with weight more than $90 \%$ of cases of insulin resistance, decreased adiponectin, atherogenic dyslipidemia, nonalcoholic steatohepatitis and factors associated with a proinflammatory state closely associated with increased cardiovascular risk [1].

Obesity is a complex multifactorial nutritional status, genetic cause, behavioral and environmental factor. It is the most common form of malnutrition in developed countries.

It is known that central fat distribution (visceral) shows a genetic predisposition, with associated environmental and hormonal factors, and in adulthood weight gain occurs more accumulation of fat in this location, which is associated with intolerance to carbohydrates or T2DM, hypertriglyceridemia and hypertension.

The body mass index (BMI) — weight in kilograms divided by the square of height in meters $\left(\mathrm{kg} / \mathrm{m}^{2}\right)$ - is the index used to classify overweight and obesity in adults. It is considered as Grade 1 (Overweight) if BMI is of 25 $29.9 \mathrm{~kg} / \mathrm{m}^{2}$, Grade 2 (Obesity) if the BMI is $30-39.9$ $\mathrm{kg} / \mathrm{m}^{2}$ and Grade 3 (morbid obesity) if the BMI is equal to or greater than $40 \mathrm{~kg} / \mathrm{m}^{2}$.

T2DM is a polygenic and multifactorial metabolic disorder in which there are two fundamental facts: first, the resistance of tissues such as muscle, liver and adipose 
tissue insulin action and, secondly, a progressive dysfunction $\beta$ cells-pancreatic may evolve as prediabetes (impaired fasting glucose, impaired glucose tolerance) or frank diabetes.

Glucose homeostasis is based on a complex interplay of multiple hormones: insulin and amylin, produced by $\beta$ cells-pancreatic glucagon, produced $\beta \psi$ cells-pancreatic, and gastrointestinal peptides including glucagon-like peptide-1 (GLP-1) and glucose-dependent insulinotropic polypeptide (GIP, gastric inhibitory polypeptide). The abnormal regulation of these substances can contribute to the clinical presentation of diabetes.

There is a clear correlation between type 2 diabetes and obesity, especially abdominal character and in connection with insulin resistance, although there may be cases of insulin resistance without obesity and not all obese people have insulin resistance and T2DM. However, the epidemic of DM2 is very even with obesity, and it has motivated the proposal of the term diabesity.

Resources are needed for research on interventions for primary prevention and treatment of obesity, and well designed studies on a large scale in this area for effective treatments and to identify risk groups.

The role of gastrointestinal peptides on glucose homeostasis is the incretin effect, by which the oral glucose exerts a greater stimulatory effect on insulin secretion glucose intravenously. The GLP-1 is produced in L cells of the small intestine and secreted in response to ingestion that stimulates the secretion of glucose-dependent insulin and inhibites glucagon. In DM2, the GLP-1 levels are decreased. Its half-life is a few minutes to be degraded by the enzyme dipeptidyl peptidase IV (DPP-IV), so it has developed GLP-1 analogs that resist degradation of DPP-IV: Exenatide is the synthetic version of exendin-4, resistant to DPP-IV degradation and has a longer half-life, delayed gastric emptying, suppresses glucagon inappropriately high levels and promotes weight loss. It has been used as adjunctive therapy to improve glycemic control in patients treated with metformin conDM2 alone or in combination with sulfonylurea, who have failed to improve their glycemic control. Exenatide is indicated in diabetic patients who could not be controlled by oral medications [2].

Exenatide improves glycemic control in several ways:

- Increases pancreatic insulin release in response to food intake [3].

- Suppresses the release of glucagon in response to meals, which prevents the liver to overproduce sugar when not needed, which prevents hyperglycemia.

- Slows gastric emptying, which reduces the amount of glucose from food that appears in the blood.

- Reduces appetite and promotes satiety through hypothalamic receptors. Most patients using exenatide lose weight slowly, and generally the greater weight loss is achieved in those with greater overshoot at the start of treatment. It has been shown that weight-lowering effect is maintained for more than two years of continuous use.

- Reduces liver fat content, especially patients with DM2 [4].

\section{Objectives}

- Report a case of type 2 diabetic patients with morbid obesity treated with exenatide.

- To determine whether treatment with exenatide are improved biochemical and physical parameters.

- To determine whether treatment with exenatide prevents bariatric surgery.

\section{Results of Case Report}

56 years old male patient treated with metformin every 12 hours for glucose intolerance, weight gain consultation in the last 6 months. Weight: $120 \mathrm{~kg}$ Height: $171 \mathrm{~cm}$, BMI: $41.01 \mathrm{~kg} / \mathrm{m}^{2}$, BP 120/75, Waist circumference: 120 cm capillary basal plasma glucose: $156 \mathrm{mg} / \mathrm{dl}$, HbA1c: 7.4. Treatment: Metformin 850/12 horas, 1500 kcal diet, AAS 100/24 horas, Atorvastatin $20 \mathrm{mg} / 24$ horas, Enalapril $20 \mathrm{mg} / 24$ horas, Carvedilol $6.25 \mathrm{mg} / 12$ horas, isosorbidemononitrate retard/24 hours.

This raises the patient to start treatment with exenatide 5 micrograms to avoid the option of bariatric surgery and improve glycemic control and body weight. The patient agreed to the initiation of drug treatment mainly due to the reason for consultation (morbid obesity).

After completing the study of patient noted an improvement in glycated hemoglobin levels of 2 points and decreased body weight by 20.8\%, 20.8\% BMI, waist circumference in $18.33 \%$, and improved lipid profile highlighting a $15 \%$ increase in HDL cholesterol. There were no changes in liver or kidney function or TSH levels (Table 1).

Regarding side effects, the patient had mild nausea for the start of treatment with exenatide 5 micrograms, which subsided with continued treatment. In step 5 to 10 micrograms of the drug, there were no side effects.

\section{Discussion}

To reduce caloric intake was taken into account the patient's weight, age, sex, degree of adiposity, desired weight and daily physical activity, establishing a lowcalorie diet of $1500 \mathrm{kcal}$.

The goals of weight reduction in most non-morbidly obese subjects are between $5 \%-10 \%$ of body weight. However, these objectives moderate weight loss are not sufficient to reduce other diseases coexisting with morbid obesity, especially type 2 diabetes, since the minimum 
Table 1. Parameters of the patient, at basal, 3, 6 and 12 months of treatment.

\begin{tabular}{ccccc}
\hline & BASAL & $3 \mathrm{MONTHS}$ & $6 \mathrm{MONTHS}$ & $12 \mathrm{MONTHS}$ \\
\hline Weight & $120 \mathrm{~kg}$ & $112 \mathrm{~kg}$ & $107.3 \mathrm{~kg}$ & $95 \mathrm{~kg}$ \\
BMI & $41.04 \mathrm{~kg} / \mathrm{m}^{2}$ & $38.30 \mathrm{~kg} / \mathrm{m}^{2}$ & $36.59 \mathrm{~kg} / \mathrm{m}^{2}$ & $32.49 \mathrm{~kg} / \mathrm{m}^{2}$ \\
Waist Perimeter & $120 \mathrm{~cm}$ & $115 \mathrm{~cm}$ & $105 \mathrm{~cm}$ & $98 \mathrm{~cm}$ \\
Glucose & $166 \mathrm{mg} / \mathrm{dl}$ & $140 \mathrm{mg} / \mathrm{dl}$ & $120 \mathrm{mg} / \mathrm{l}$ & $108 \mathrm{mg} / \mathrm{dl}$ \\
Creatinine & $0.86 \mathrm{~g} / \mathrm{dl}$ & $0.8 \mathrm{mg} / \mathrm{dl}$ & $0.85 \mathrm{mg} / \mathrm{dl}$ & $0.82 \mathrm{mg} / \mathrm{dl}$ \\
GOT/GPT/GGT & $20 / 22 / 27 \mathrm{U} / \mathrm{L}$ & $24 / 33 / 17 \mathrm{U} / \mathrm{L}$ & $21 / 31 / 22 \mathrm{U} / \mathrm{L}$ & $21 / 26 / 21 \mathrm{U} / \mathrm{L}$ \\
Tryglicerides & $193 \mathrm{mg} / \mathrm{dl}$ & $178 \mathrm{mg} / \mathrm{dl}$ & $121 \mathrm{mg} / \mathrm{dl}$ & $110 \mathrm{mg} / \mathrm{dl}$ \\
HDL-cholesterol & $46 \mathrm{mg} / \mathrm{dl}$ & $41 \mathrm{mg} / \mathrm{dl}$ & $50 \mathrm{mg} / \mathrm{dl}$ & $53 \mathrm{mg} / \mathrm{dl}$ \\
LDL-cholesterol & $100 \mathrm{mg} / \mathrm{dl}$ & $94 \mathrm{mg} / \mathrm{dl}$ & $85 \mathrm{mg} / \mathrm{dl}$ & $82 \mathrm{mg} / \mathrm{dl}$ \\
Total Cholesterol & $205 \mathrm{mg} / \mathrm{dl}$ & $185 \mathrm{mg} / \mathrm{dl}$ & $167 \mathrm{mg} / \mathrm{dl}$ & $158 \mathrm{mg} / \mathrm{dl}$ \\
Glycosylated Hemoglobin & $7.4 \%$ & $6.5 \%$ & $5.8 \%$ & $5.4 \%$ \\
Blood Pressure & $125 / 75 \mathrm{~mm} / \mathrm{Hg}$ & $120 / 70 \mathrm{~mm} / \mathrm{Hg}$ & $120 / 75 \mathrm{~mm} / \mathrm{Hg}$ & $125 / 70 \mathrm{~mm} / \mathrm{Hg}$ \\
Albumin/creatinine & $11 \mathrm{mg} / \mathrm{g}$ & $10 \mathrm{mg} / \mathrm{g}$ & $10 \mathrm{mg} / \mathrm{g}$ & $9.97 \mathrm{mggUI} / \mathrm{ml}$ \\
TSH & $0.92 \mathrm{mcgUI} / \mathrm{ml}$ & $0.98 \mathrm{mcgUI} / \mathrm{ml}$ & & $0.77 \mathrm{mcgUI} / \mathrm{ml}$ \\
\hline
\end{tabular}

level considered necessary to objectify changes in this sense is found in $10 \%$, in our patient achieved a decrease of $20.8 \%$, achieving a good control of type 2 diabetes mellitus coexisting with morbid obesity.

Nutritional strategies and changes in lifestyle with the intention of reducing the impact of DM2 associated with morbid obesity are often ineffective in the long term. In this sense, bariatric surgery has emerged as almost the only useful therapeutic alternative for significantly reducing weight in morbidly obese subjects and at the same time, solve a high percentage of patients DM2. Bariatric surgery improves obesity and its comorbidities in adults with complicated morbid obesity [5]. The role of bariatric surgery in this group of patients, with or without the help of certain drugs is yet to be elucidated [6].

In recent years, the most attractive hypothesis about the mechanisms by which bariatric surgery may be curative for type 2 diabetes in obese subjects have come from the hand of understanding the role of gastrointestinal hormones in obesity and diabetes. The use of exenatideslowed gastric emptying and decreased the patient's appetite, thereby helping to reduce body weight [7].

The use of these drugs should be part of a fully integrated program that emphasizes proper diet, exercise and behavioral modification [8-10].

Exenatide achieved a significant reduction in HbA1c by $1 \%$, whereas in our study was achieved by $2 \%$ and this decline continued and sustained weight loss with improvement in cardiovascular risk factors like blood pressure and lipids. Weight loss was dose dependent and progressive [11].

\section{Conclusion}

Drug therapy for morbid obesity is only acceptable if done in the framework of a comprehensive program of weight loss, prevention of comorbidities, including health education, changes in lifestyles, diet and exercise. These drug treatments are indicated mainly in obese individuals who do not respond to standard measures. The role of bariatric surgery, with or without the use of exenatide, is subject to further research to elucidate its role among the various treatment options for these patients. Exenatide treatment in patients with morbid obesity may represent a therapeutic complement of inestimable value, with minimal side effects (mild nausea and dyspeptic symptoms) [12-16], cardiovascular protection by improving the lipid profile and glycemic and as an alternative to bariatric surgery.

\section{REFERENCES}

[1] F. J. Tebar Masso and F. J. Escobar, "Diabetes Mellitus in Clinical Practice,” Pan American Publishing, Los Angeles, 2009.

[2] “CDER Drug and Biologic Approvals for Calendar Year 2005,” U.S. Food and Drug Administration, 2008.

[3] M. C. Buncke, M. Diamant, A. Corner, B. Eliasson, J. L. Malloy, R. M. Shaginian, et al., "One-Year Treatment with Exenatide Improves Beta-Cell Function, Insulin Compare with Glargine, in Metformin-Treat Type 2 Di- 
abetic Patients: A Randomized, Controlled Trial,” Diabetes Care, Vol. 32, No. 5, 2009, pp. 762-768. http://dx.doi.org/10.2337/dc08-1797

[4] M. E. Tushuizen, C. M. Buncke, P. J. Pouwels, J. H. van Waesberghe, M. Diamant and R. J. Heine, "Incretinmimetics as a Novel Option for Hepatic Steatosis Therapeutic,” Liver Internatioanl, Vol. 26, No. 8, 2006, pp. 10151017. http://dx.doi.org/10.1111/j.1478-3231.2006.01315.x

[5] T. D. Adams, R. E. Gress, S. C. Smith, et al., "LongTerm Mortality after Gastric Bypass Surgery,” The New England Journal of Medicine, Vol. 357, No. 8, 2007, pp. 753-761. http://dx.doi.org/10.1056/NEJMoa066603

[6] R. Nandagopal, R. J. Brown and K. I. Rother, "Resolution of Type 2 Diabetes Following Bariatric Surgery: Implications for Adults and Adolescents,” Diabetes Technology \& Therapeutics, Vol. 12, No. 8, 2010, pp. 671-677. http://dx.doi.org/10.1089/dia.2010.0037

[7] D. G. Parkes, R. Pittner, C. Jodka, et al., "Insulinotropic Actions of Exendin-4 and Glucagon-Like Peptide 1 in Vivo and in Vitro," Metabolism, Vol. 50, No. 5, 2001, pp. 583-589. http://dx.doi.org/10.1053/meta.2001.22519

[8] K. G. Alberti, P. Zimmet and J. Shaw, "Metabolic Syndrome-A New Worldwide Definition. A Consensus Statement from the International. Diabetes Federation,” Diabetic Medicine, Vol. 23, No. 5, 2006, pp. 469-480. http://dx.doi.org/10.1111/j.1464-5491.2006.01858.x

[9] G. S. Berenson, S. R. Srinivasan, W. Bao, W. P. Newman 3rd, R. E. Tracy and W. A. Wattigney, "Association between Multiple Cardiovascular Risk Factors and Atherosclerosis in Children and Young Adults. The Bogalusa
Heart Study,” The New England Journal of Medicine, Vol. 338, No. 23, 1998, pp. 1650-1656. http://dx.doi.org/10.1056/NEJM199806043382302

[10] N. M. McGrath, G. N. Parker and P. Dawson, "Early Presentation of Type 2 Diabetes Mellitus in Young New Zealand Maori,” Diabetes Research and Clinical Practice, Vol. 43, No. 3, 1999, pp. 205-209. http://dx.doi.org/10.1016/S0168-8227(99)00003-0

[11] A. Fleischman and E. T. Rhodes, "Management of Obesity, Insulin Resistance and Type 2 Diabetes in Children: Consensus and Controversy," Diabetes, Metabolic Syndrome and Obesity, Vol. 2, 2009, pp. 185-202.

[12] M. C. Riddle, R. R. Henry, T. H. Poon, et al., "Exenatide Elicits Sustained Glycemic Reduction and Control of Body Weight Progressive in Patients with Type 2 Diabetes Inadequately Controlled by Sulphonylureas with or without Metformin,” Diabetes/Metabolism Research and Reviews, Vol. 22, No. 6, 2006, pp. 483-491. http://dx.doi.org/10.1002/dmrr.646

[13] “2007 Safety Alerts for Drugs, Biologics, Medical Devices, and Dietary Supplements," U.S. Food and Drug Administration, 2008.

[14] Byetta (Exenatide) FDA Warning. http://www.fda.gov/safety/medwatch/safetyinformation/s afetyalertsforhumanmedicalproducts/ucm079781.htm

[15] "Lilly’s Once-Weekly Byetta May Have Cancer Risk," Pharmalot News, 2010.

[16] F. Halperin, J. R. Ingelfinger and G. T. McMahon, "Management of Type 2 Diabetes-Polling Results,” The New England Journal of Medicine, Vol. 358, No. 7, 2008, p. e8. 